\title{
Postcolonial Reflections on the Mnemonic Confluence of the Holocaust, Stalinist Crimes, and Colonialism
}

\author{
Jie-Hyun Lim
}

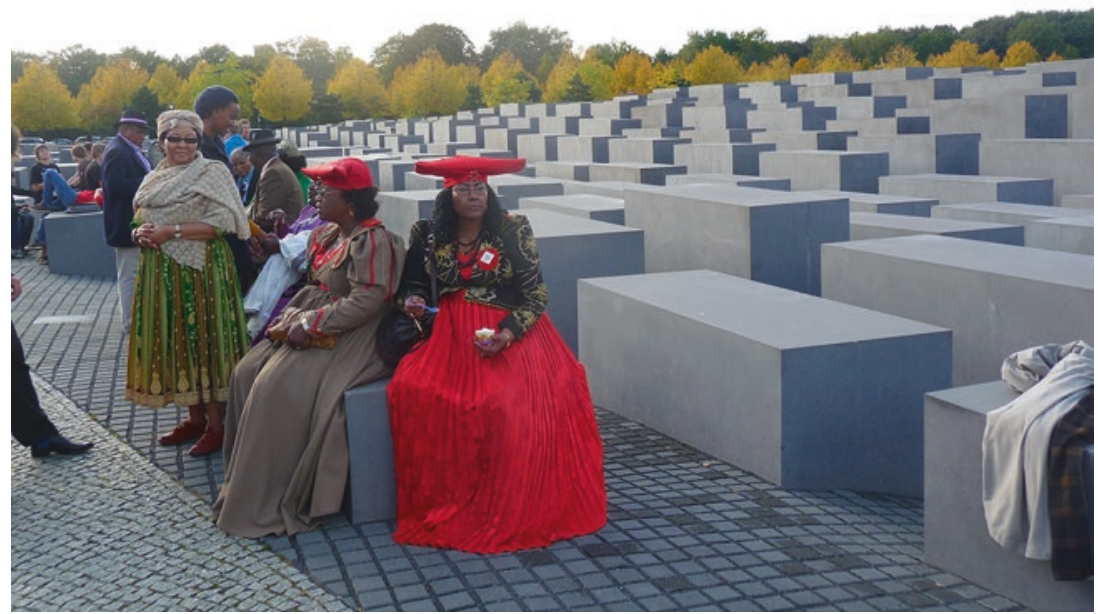

Fig. 2.1 Descendants of the 1904-1908 genocide in Namibia at the Holocaust Memorial in Berlin 2011, on the occasion of the first repatriation of deported human remains to Namibia (Reinhard Kößler)

(C) The Author(s) 2021

J.-H. Lim, E. Rosenhaft (eds.), Mnemonic Solidarity, Entangled Memories in the Global South, https://doi.org/10.1007/978-3-030-57669-1_2 
Abstract Lim sets out the origins and progress of the mnemonic confluence of three historical traumas - the Holocaust, the crimes of colonialism, and Stalinist terror. He traces this process back to the "thaw" in memory cultures precipitated by the end of socialism after 1989, and adopts a postcolonial perspective to analyze how victimhood memories arising out of these experiences have become entangled globally. Against the flat model of the cosmopolitanization of the Holocaust, Lim argues for the non-hierarchical comparability of historical traumas. He concludes by proposing "critical relativization" and "radical juxtaposition" as ways of de-hegemonizing and de-centering universal memories and deconstructing mnemonic nationalism.

Keywords Global memory formation $\bullet$ Holocaust $\bullet$ Stalinism - Genocide • Postcolonialism • Critical relativization • Radical juxtaposition

\section{Victimhood Claims at the Thaw of Cold War MEMORY}

One of the salient features of postwar global memory formation is that the Holocaust has provided a memory template for historical traumas everywhere. ${ }^{1}$ American slavery, the genocide of the indigenous nations of the New World, countless colonial atrocities in the global South, the Japanese A-bomb victims, the Nanjing Massacre, American war crimes in Vietnam, and the Korean comfort women (victims of military sexual slavery) are commemorated in terms drawn from the vocabulary of Holocaust memory. In Central and Eastern Europe, the painful memories of the Allied bombing and Vertreibung in Germany, the mass killing and enslavement of the Slavs in "Germany's Wild East," and the Ukrainian Holodomor and

${ }^{1}$ Daniel Levy and Natan Sznaider, The Holocaust and Memory in the Global Age, trans. Assenka Oksiloff (Philadelphia: Temple University Press, 2006).

J.-H. Lim $(\bowtie)$

Department of History and the Critical Global Studies Institute, Sogang University, Seoul, Republic of Korea e-mail: limjiehyun@gmail.com 
other Stalinist crimes have invoked the memory of Holocaust. ${ }^{2}$ But Daniel Levy and Natan Sznaider's remark that, by transposing Holocaust memory onto memories of other genocides, "Never again Auschwitz provided the foundation for emerging cosmopolitan memories" is both right and wrong. ${ }^{3}$ In the fifteen years since their book was written, it has become clear that Holocaust discourse is increasingly providing the mnemonic leverage for the re-territorialization and nationalization of collective memory.

Holocaust memory has been instrumentalized, vulgarized, and abused. Through the narcissistic identification with Jewish suffering, postcommunist politics in Eastern Europe nationalized Holocaust remembrance to justify a resurgent old-fashioned ethnic nationalism and activate a screen memory to cover up their own war crimes. ${ }^{4}$ Also, one cannot but to see an inherent contradiction between the global ubiquity of the Holocaust and its supposed uniqueness. This chapter scrutinizes the mnemonic confluence and entanglements of three historical traumas-the Holocaust, colonial genocide, and Stalinist terror-in the global memory space. In particular, it explores the ways in which memories of those events have been deployed to underpin the claims of whole polities (nationstates) to the status of victim and to the material and ethical entitlements arising from that status. As these claims have become entangled in

\footnotetext{
${ }^{2}$ It is not my purpose here to assess the objective force of historical comparisons/analogies, a theme which has also, of course, been present in recent political theory and historiography. See, for example, Giorgio Agamben, Homo Sacer: Sovereign Power and Bare Life, trans. Daniel Heller-Roazen (Stanford: Stanford University Press, 1998); A. Dirk Moses, "Conceptual Blockages and Definitional Dilemmas in the 'Racial Century': Genocides of Indigenous Peoples and the Holocaust," Patterns of Prejudice 36, no. 4 (2020): 7-36; Jan Burzlaff, "The Holocaust and Slavery? Working Towards A Comparative History of Genocide and Mass Violence," Journal of Genocide Research (2020), https://doi.org/10.108 0/14623528.2020.1718355; Steven T. Katz, "Response to Jan Burzlaff's Review of Steven T. Katz, The Holocaust and New World Slavery," Journal of Genocide Research (2020), https://doi.org/10.1080/14623528.2020.1718357.

${ }^{3}$ Daniel Levy and Natan Sznaider, "Memory Unbound: the Holocaust and the Formation of Cosmopolitan Memory," European Journal of Social Theory 5, no. 1 (2002): 87-106 (here 99).

${ }^{4}$ Lea David, "Holocaust Discourse as a Screen Memory: the Serbian Case," in History and Politics in the Western Balkans: Changes at the Turn of the Millennium, eds. Srdan M. Jovanovic and Veran Stancetic (Belgrade: The Center for Good Governance Studies, 2013), 64-88 (here 65, 67, 69, 71, 79); Jelena Subotić, Yellow Star, Red Star: Holocaust Remembrance after Communism (Ithaca: Cornell University Press, 2019), 5-11.
} 
globalized discourse, competition for recognition of national grievance has intensified.

The key moment in this development came in the 1990s, as official memories frozen by the Cold War ideology began to thaw. This thaw released suppressed memories all over the world. In the former Soviet bloc, the official myths of anti-fascist struggle lost their power as screen memories, ${ }^{5}$ and vernacular remembrance of the Stalinist terror erupted into the public sphere. At the same time, there emerged previously unspoken memories of Nazi collaboration in Eastern Europe, triggering an East European version of the Historikerstreit which had convulsed West Germany in the decade before the Wall came down. In the tri-continent of Asia, Africa, and Latin America, the fall of communism also signaled the release of memories of the atrocities committed by Western colonialisms. Memories of colonial genocide and anti-communist political atrocities could no longer be marginalized, because the propaganda imperative to defend Western civilization against Soviet barbarism lost its power. The colonial scars sutured by the worldwide anti-communist alliance became porous, and it became possible to articulate the hurts of colonial occupation and economic imperialism as such before a global public.

In the post-Cold War environment, the victimhood claims arising from those historical traumas become entangled, producing a global memory formation. By this I mean neither the global memory space as a fact or a condition, nor the simple compilation or comparative juxtaposition of separate memories within it. Formation here denotes process, and scrutiny of how this triad of victimhoods has become entangled can shed new light on the dynamics of that process in the twenty-first century. Global memory formation is in a constant state of becoming, and its outcomes depend on specific mnemonic interactions between the global template (in this case Holocaust and to a lesser extent colonialism) and local sensitivities. This chapter traces some key interactions and considers the possibilities for mnemonic solidarity they contain (and how they have been frustrated). The Historikerstreit of the 1980s introduced the term "relativization" to characterize arguments that juxtaposed the crimes of the Nazis and Bolshevik terror with the purpose of diminishing the enormity of the Holocaust and "moving beyond" West Germany's public culture of

\footnotetext{
${ }^{5}$ On the origins and uses of the term "screen memory," see Michael Rothberg, Multidirectional Memory: Remembering the Holocaust in the Age of Decolonization (Stanford: Stanford University Press, 2009), 12-16.
} 
historical self-reflection and apology. This chapter ends by affirming the value of remembering historical traumas together and in relation to one another, but calls for a critical approach that resists political instrumentalization and the temptation to create hierarchies of victimhood by deploying strategies of "critical relativization" and "radical juxtaposition."

\section{(Post)Colonial and Holocaust Identities:}

\section{Alibis and Alliances}

Amid the refugee crisis that shook Europe in September 2015, a debate broke out among Polish historians on how to interpret Eastern European apathy or even antipathy toward Islamic refugees. Gazeta Wyborcza's report about remarks by Jan Gross sparked the controversy. In an article in Die Welt, he had claimed that East European hostility toward the refugees originated in a failure to come to terms with the Holocaust past. Gross argued that critical reflection on Eastern Europeans' complicity in the murder of the Jews might have resulted in more empathy with refugees. He asserted that Poles even murdered more Jews than Germans, challenging the myth of the unity of the resistance to German occupation. ${ }^{6}$ Since Gross has been arguing for Polish complicity in the Holocaust since the publication of Neighbors in 2000, his article in Die Welt is not very surprising.

Even so, Gross's point is intriguing. He was suggesting that Eastern European attitudes to Islamic refugees reflect a "wrong" memory practice-challenging the relativization or marginalization of the Holocaust in the Polish mnemoscape. In Eastern Europe, Nazism and communism figure as twin evils in post-Communist memory, with communism widely regarded as the greater evil in its duration, intensity, and temporal proximity. Particularly in the Baltics and Poland, the Holocaust has been regarded as peripheral to national suffering under Stalinist oppression. ${ }^{7}$ Gross's argument targeted the relativization or marginalization of the Holocaust in the Polish mnemoscape.

\footnotetext{
${ }^{6}$ Bartosz T. Wieliński, “'Polska nie chce uchodźców, bo nie rozliczyła się ze zbrodni na Żydach.' Oburzenie po tekście Grossa," Wyborcza.pl, September 15, 2015, http://wyborcza.pl/1,75968,18817369,skandalista-gross.html\#ixzz420HIHBty.

${ }^{7}$ Siobhan Kattago, "Agreeing to Disagree on the Legacies of Recent History Memory, Pluralism and Europe after 1989," European Journal of Social Theory 12, no. 3 (2009): 375-95 (here 382); Martin Evans, "Memories, Monuments, Histories: the re-thinking of the Second World War since 1989," National Identities 8, no. 4 (2006): 317-48 (here 320).
} 
Polish historians Marcin Zaremba and Aleksander Smolar came to the defense of the Poles by pointing to the absence of a colonial past in Poland and other Eastern European countries. Unlike Western Europeans (including Germans), who have historical experience of ruling over colonial subjects, they argued, Poles have had no chance to become familiar with people of different cultures, religions, and/or race. Poland has never been a colonial power that had to deal with a native Other. ${ }^{8}$ Paradoxically, the discursive connectivity of anti-Semitism and Islamophobia is no secret in contemporary Poland, as manifested in the widespread joke that "we are ready to accept refugees because we have always had concentration camps." But the implication of Zaremba and Smolar's argument was a specifically anti-colonial indictment: "You are guilty of colonialism, but we are innocent. So the refugee problem belongs to you." From the postcolonial viewpoint, we can say that their anti-colonial rhetoric bespeaks the ambivalence of Polish Orientalism: the aspiration to be included into Western Europe while orientalizing the imagined internal other within Poland.

A cursory look at the history of Poland's partition by Russia, Austria, and Prussia, the trajectories of national irredentism, and the suffering of the Polish nation at large may give credence to the notion of Poland's colonial innocence. But Poland was the colonizer against the Lithuanian and Ukrainian neighbors in the kresy (borderland) at the same time as German settlers were colonizing Poland. Treated as a hinterland, the first model of underdevelopment, and "a neglected suburb of Europe," Poles have never been free of the West's "intellectual project of demiOrientalization." 10 But they have responded by developing disrespectful attitudes toward other "more eastern" and "less western" Slavic neighbors. And this reflects Poland's status as subaltern empire: subaltern

${ }^{8}$ Wieliński, “'Polska nie chce uchodźców, bo nie rozliczyła się ze zbrodni na Żydach.'; Aleksander Smolar, "Smolar: Gross szokuje," Wyborcza.pl, September 16, 2015, http:// wyborcza.pl/1,75968,18824173,smolar-gross-szokuje.html.

${ }^{9}$ Marek Rymsza, "Dyskusja: czy to nasza sprawa?” Więź 4, no. 662 (2015): 36-46 (here 42).

${ }^{10}$ Lucy Mably et al., “'Other' Posts in 'Other' Places: Poland through a Postcolonial Lens?” Sociology 50, no. 1 (2016): 60-76 (here 66); Larry Wolff, Inventing Eastern Europe: The Map of Civilization on the Mind of the Enlightenment (Stanford: Stanford University Press, 1994), 9; Jerzy Jedlicki, A Suburb of Europe: Nineteenth-Century Polish Approaches to Western Civilization (Budapest: Central European University Press. 1999), xiii. 
vis-à-vis Germany and the "West," yet fully incorporated in the global structure of domination as the repressive local agent of the great powers. ${ }^{11}$ It is this complex situation that fueled Vladimir Putin's anti-Polish campaign in the run-up to the 75th anniversary of the liberation of Auschwitz in 2020. Poland's ambivalent position under Nazi occupation provided the excuse for Putin to whitewash Stalin's handshake with Hitler and erase the first two years of World War II. ${ }^{12}$

Internal colonialism, too, was entirely characteristic of Poland's Second Republic (1918-1939). This was a multi-ethnic state, where ethnic Poles formed only about $68.9 \%$ of the whole population. The rest were Ukrainians, Jews, Belorussians, Germans, and others. Polish nationalists regretted that it remained "not a nation-state but a state of nationalities." "13 Józef Piłsudski's Sanacja regime responded to the demands of ethnic minorities by setting up the internment camp at Bereza Kartuska in 1934. Internal colonialism, demi-Orientalism against the kresy (borderlands) and Eastern Slavic neighbors, and the fusion of anti-Semitism and anti-Bolshevism in official discourse colluded rhetorically with the anti-Slavic and anti-Semitic propaganda that would mark the Nazi colonial occupation of Poland itself. Polish nationalism was no exception to the "ambivalent hybrid" of desire and resentment typical of subaltern imperialists.

What Poland lacks is not colonial experience, but postcolonial criticism toward internal colonialism. In the communist era, hundreds of thousands of contract workers from Asia and Africa flowed into East Germany, Poland, Czechoslovakia, and the Baltic Soviet republics. This evidences the existence of a "global socialist ecumene" which promoted

\footnotetext{
${ }^{11}$ For Subaltern Empire, see Viatcheslav Morozov, "Subaltern Empire? Toward a Postcolonial Approach to Russian Foreign Policy," Problems of Post-Communism 60, no. 6 (2013): 16-28; Jordan Sand, "Subaltern Imperialists: The New Historiography of the Japanese Empire," Past and Present, no. 225 (November 2014): 273-88.

${ }^{12}$ Anshel Pfeffer, "In New Battle Over Auschwitz Legacy, Poland Falls Victim to Holocaust Geopolitics," Haaretz, January 22, 2020, https://www.haaretz.com/israel-news/.premium-the-dirty-politics-behind-israel-s-capitulation-to-putin-s-wwii-revisionism-1.8406565/.premium-the-dirty-politics-behind-israel-s-capitulation-to-putin-swwii-revisionism-1.8406565; Ofer Aderet, “The Dirty Politics Behind Israel's Capitulation to Putin's WWII Revisionism," Haaretz, March 8, 2020, https://www.haaretz.com/israelnews/.premium-auschwitz-75-years-israel-yad-vashem-poland-victim-holocaust-geopolitics-putin-1.8432285/.premium-auschwitz-75-years-israel-yad-vashem-poland-victimholocaust-geopolitics-putin-1.8432285.

${ }^{13}$ Janusz Pajewski, Budowa Drugiej Rzeczypospolitej 1918-26 (Kraków: PAU, 1995), 164.
} 
transnational flows of ideas, knowledge and cultural artifacts and the transnational mobility of people. And this ecumene did not come to an end even after the collapse of the communist bloc. The fact that Poland has accepted 100,000 Chechen refugees or exiles since 1996 refutes the proposition that Islamophobia is a fixed memory template in post-communist Poland. But while these numbers are impressive, the recent refugee crisis has seen a dramatic shift from empathy to apathy in the Polish attitude toward Chechens. ${ }^{14}$

In short, the debate over the refugee question is not a factological, but an epistemological one, in which collective guilt for anti-Semitism and colonial innocence are competing to provide the narrative template for post-communist collective memory. Gross's criticism that Polish society's hostility to Islamic refugees represents its failure to come to terms with the past of the Holocaust makes sense, but it is only partially correct. The blunt insensitivity toward them even among critical intellectuals really does bespeak the absence of postcolonial self-criticism. It is the combination of tropes that counts, though: the memory of colonial victimization under Nazism and Stalinism operates as a screen memory to suppress the knowledge of complicity in the Holocaust. The "Historikerstreit po polsku," a heated debate around Jan Błoński’s seminal essay "Biedny polacy patrzą na getto" (poor Poles look at the ghetto) in 1987, followed by the reception of Jan Gross's book Sasiedzi (Neighbors) in 2000, led to "a genuine moral revolution" in post-communist Poland by breaking through the anti-fascist screen memory and bringing suppressed guilt to the surface. However, even the metamorphosis of Polish self-definition from innocent victim to "Homo Jedvabnecus" after 2000 did not produce a critical postcolonial response. Poland is still waiting for a mnemonic confluence of the Holocaust and the postcolonial that does justice to the complexity of its wartime experiences.

Outside the realm of political rhetorics, postcolonial readings of the Holocaust have elaborated the historical continuities between German colonial genocide, the Nazis' Eastern occupation policy, and the Holocaust, helping us to situate the German invasion and occupation of the Slavic East firmly in the European colonialist tradition. ${ }^{15}$ The Generalplan Ost

\footnotetext{
${ }^{14}$ See a Chechen refugee resident in Poland-Malika Abdoulvakhabova's witness: Rymsza, “Dyskusja: czy to nasza sprawa?” Wiez 662 (2015): 36-46 (here 36, 38, 39).

${ }^{15}$ Jürgen Zimmerer, "Die Geburt des Ostlandes aus dem Geiste des Kolonialismus: Die nationalsozialistische Eroberungs- und Beherrschungspolitik in (post-)kolonialer
} 
assumed that the SS would run latifundia in the occupied territories exploiting native Slav labor until the Germans were numerous and mechanized enough to do without them. To German settlers in the occupied Generalgouvernement, pioneering in the East was "colonial work" like work under the African sun. As Reich Economic Minister Walter Funk wrote, "vast territories of the European East will be Europe's promising colonial land of the future." 16 By blaming Poland's backwardness on the Jewish influence, moreover, some Nazis could combine the rationale of Germany's civilizing mission with crusading anti-Semitism. In short, Nazism was an "intra-European colonialism."17

In Europe, there has been emotional resistance to situating Nazism and the Holocaust within the context of global colonialism. An implicit Eurocentrism insists that "the Holocaust stands out from other genocides because it was committed in the heart of civilized Europe rather than in the midst of (supposedly) primitive or barbaric societies." 18 Zygmunt Bauman anticipated this argument thirty years ago, with his warning that Holocaust-style genocide is a logical outcome not of premodern barbarity, but of Western modernity. ${ }^{19}$ And as early as 1950 Aimé Césaire pinpointed the dilemma of Eurocentric intellectuals: "[The European bourgeois] has a Hitler inside him ... and ... what he cannot forgive Hitler for is not the crime in itself, the crime against man, it is not the bumiliation of man as such, it is the crime against the white man, and the fact that he applied to Europe colonialist procedures which had until then been reserved

Perspektive," Sozial Geschichte 19, no. 1 (2004): 10-43; Benjamin Madley, "From Africa to Auschwitz: How German South West Africa Incubated Ideas and Methods Adopted and Developed by the Nazis in Eastern Europe," European History Quarterly 35, no. 3 (2005): 429-64; Enzo Traverso, The Origins of Nazi Violence (New York: The New Press, 2003); Robert Gerwarth and Stephan Malinowski, "Der Holocaust als kolonialer Genozid? Europäische Kolonialgewalt und nationalsozialistischer Vernichtungskrieg," Geschichte und Gesellschaft 33 (2007): 439-66; A. Dirk Moses, "Empire, Colony, Genocide: Keywords and the Philosophy," in Empire, Colony, Genocide, ed. A. Dirk Moses (New York and Oxford: Berghahn Books, 2008), 3-54.

${ }^{16}$ David Furber, "Near as Far in the Colonies: The Nazi Occupation of Poland," The International History Review 26, no. 3 (2004): 541-79 (here 541, 544, 549).

${ }^{17}$ Moses, "Empire, Colony, Genocide: Keywords and the Philosophy," 34.

${ }^{18}$ Dan Stone, "The Historiography of Genocide: Beyond 'Uniqueness' and Ethnic Competition," Rethinking History 8, no. 1 (2004): 127-42 (here 133).

${ }^{19}$ Zygmunt Bauman, Modernity and the Holocaust (Ithaca: Cornell University Press, 2000), xi-xii, 28, 152 and passim. 
exclusively for the Arabs of Algeria, the 'coolies' of India, and the 'niggers' of Africa." ${ }^{20}$ Remarkably, People's Poland published a translation of Césaire's Discours sur le colonialisme early in 1950 - an example of how Poland's communist postcolonialism drew an analogy between the Slavic East under the Nazi occupation of the "Third Europe" and the postcolonial states of the "Third World." 21 This analogy is strikingly absent from the work of post-communist liberal historians in Poland, who still (or again) suffer the ambivalent feelings of envy, admiration, and distrust toward Western Europe which shaped the mentalité of the nineteenthcentury intelligentsia and which bespeak the country's triple position as former colony, former colonizer, and subject to Western hegemons.

But as the case of Aimé Césaire reminds us, the perception of a family resemblance between Nazi racism and colonialism in Europe and the oppressions of (internal) colonialism and the racial state elsewhere was present in the observations of Afro-diasporic intellectuals from a very early stage. The confluence of anti-Semitism and racism can be found in W. E. B. Du Bois' memory of an incident during his trip to Galicia in 1890, when a small-gown cabman asked if Du Bois wanted to stop "Unter die Juden," in a local hotel run by a Jew. To that cabman, Du Bois, an African-American, was no different from a Jew. And the fact that Germans were more hostile to Jews than to him as a "Negro" taught him that racism is about more than color prejudice. ${ }^{22}$ Galician Jews and African Americans were entangled that way in the late nineteenth century. Nor was Du Bois the first to recognize those entanglements. The Black Atlantic slave communities strengthened their self-esteem by seeing their oppression and their hopes through the lens of the Jewish exodus from slavery in Egypt, revaluing their suffering as a redemptive experience. ${ }^{23}$

Di Shklaferay, the Yiddish version of the Uncle Tom's Cabin, is a good example of the "return traffic" in this exchange. Ayzik-Meyer Dik adapted the novel to Jewish circumstances, making the master a Jew, and having Uncle Tom escape to freedom in Canada with the Jewish master's kind

\footnotetext{
${ }^{20}$ Aimé Césaire, Discourse on Colonialism, trans. J. Pinkham (New York: Monthly Review, $2000), 36$.

${ }^{21}$ Adam F. Kola, Socjalistyczny Postkolonializm: Rekonsolidacja pamięci (Toruń: NCU Press, 2018), 2-3.

${ }^{22}$ W. E. B. Du Bois, "The Negro and the Warsaw Ghetto," in The Oxford W. E. B. Du Bois Reader, ed. Eric. J. Sundquist (Oxford: Oxford University Press, 1996), 470.

${ }^{23}$ Paul Gilroy, The Black Atlantic: Modernity and Double Consciousness (London: Verso, 1993), 207-8.
} 
help. Di Shklaferay became a bestseller among immigrant Jews to America in the late nineteenth century. The New York Yiddish newspaper Forverts compared the emancipation of American slaves with the Jewish Exodus from Egypt and in 1927 urged American Jews to watch the film of Uncle Tom's Cabin. Radical Jews sent their children to racially integrated summer camps. The spirit of solidarity between African Americans and Jews continued in the work of the NAACP, in which many liberal and radical Jews participated. In 1952 Louis Harap, the managing editor of Jewish Life, invited Du Bois to a concert-meeting in "Tribute to the Warsaw Ghetto Fighters." He asked Du Bois to speak on the "significance of the ghetto fight for the Negro people in the United States today in relation to cooperation with their allies, the Jewish people and the common people of America." 24 In his speech, Du Bois spoke of recalling "the scream and shots of a race riot in Atlanta and the marching of the Ku Klux Klan" during his visit to the ruins of the Warsaw ghetto in 1949. He acknowledged that he was able to gain a "more complete understanding of the Negro problem" through a "cleared understanding of the Jewish problem in the world." 25 The swift response by African Americans to the 1948 "Genocide Convention" is another landmark. We Charge Genocide, a petition delivered by African-American Communists to the United Nations in 1951, invoked global awareness of the Holocaust to make a link between the crimes of the Nazis and Jim Crow America. Their action met a negative response from Raphael Lemkin, the chief proponent of the genocide concept and the UN Convention, who was fearful of losing American support. $^{26}$

The dialogue of Blacks and Jews is also found in apartheid South Africa. For many prominent anti-apartheid activists, the diary of Anne Frank was a treasured text, with handwritten copies circulating even in the notorious Robben Island prison. In one of his public addresses as president of

\footnotetext{
${ }^{24}$ W. E. B. Du Bois, "Letter from Jewish Life to W. E. B. Du Bois, February 13, 1952," W. E. B. Du Bois Papers (MS 312) Special Collections and University Archives, University of Massachusetts Amherst Libraries, accessed March 8, 2020, http://credo.library.umass. edu/view/full/mums312-bl37-i103.

${ }^{25}$ Du Bois, "The Negro and the Warsaw Ghetto," 471.

${ }^{26}$ Ann Curthoys and John Docker, "Defining Genocide," in The Historiography of Genocide, ed. Dan Stone (Basingstoke: Palgrave Macmillan, 2010), 9-41 (here 16-21); David Helps, “'We Charge Genocide': Revisiting Black Radicals' Appeals to the World Community," Radical Americas 3, no. 1 (2018): 1-24 (here 9).
} 
post-apartheid democratic South Africa, Nelson Mandela remembered that Anne's diary had reinforced his confidence in the invincibility of the cause of freedom and justice. The anti-racist activists drew on the analogy with Nazism to characterize the apartheid system and to mobilize international support for the anti-apartheid movement as the most critical moral battle in the postwar world. The three successive exhibitions of "Nazisme in Zuid-Afrika" held in Anne Frank House in Amsterdam in the early 1970s, jointly organized by the Pluto (the Dutch-South African student group) and the Dutch Anti-Apartheid Movement, provide us with an excellent example of the interaction of postcolonial and Holocaust memory. Visitors could see the banner declaring "Nazism=Apartheid" and a life-size papier-mâché doll of then-Prime Minister B.J. Vorster holding a swastika. ${ }^{27}$ Black British critic Paul Gilroy's Black Atlantic and Between Camps are nothing other than the attempt to recover this history of dialogue between Blacks and Jews. The postcolonial matters in the transatlantic nexus of memories. ${ }^{28}$

\section{Nagasaki AND Auschwitz}

"Stunned by the intense air of death" during his first visit to Auschwitz in 1987, Nakatani Takeshi works as a tour guide at Poland's national Auschwitz-Birkenau museum. After passing the examination for official guides, he started working there in 1997 . He hopes the tour he leads can help Japanese visitors to understand "the suffering of victims and the importance and fragility of peace." But for him the museum does not prompt reflection on the East Asian wartime experience. ${ }^{29}$ Hirano Yumie, who serves as a "keeper of memory" of the A-bomb experience in

\footnotetext{
${ }^{27}$ Shirli Gilbert, “Anne Frank in South Africa," Holocaust and Genocide Studies 26, no. 3 (Winter 2012): 366-93 (here 366, 374).

${ }^{28}$ There is not space here to explore the growing evidence for exchanges across the "Black Pacific," but see Yuichiro Onishi, "The New Negro of the Pacific: How African Americans Forged Cross-Racial Solidarity with Japan, 1917-1922," Journal of African American History 92, no. 2 (2007): 191-213; Bill Mullen, Afro-Orientalism (Minneapolis: University of Minnesota Press, 2004); Yuichiro Onishi, Trans-Pacific Anti-racism: Afro-Asian Solidarity in twentieth-Century Black America, Japan, and Okinawa (New York and London: New York University Press, 2013); Etsuko Taketani, The Black Pacific Narrative: Geographic Imaginings of Race and Empire between the World Wars (Hanover, NH: Dartmouth College Press, 2014).

${ }^{29}$ Toshihisha Onishi, "Auschwitz guide works to enlighten Japanese visitors," Japan Times, March 5, 2015, https://www.japantimes.co.jp/news/2015/03/05/national/history/auschwitz-guide-works-to-enlighten-japanese-visitors/\#.WrhbWIiuyUl.
} 
Hiroshima Peace Memorial Park, has a different approach. The City of Hiroshima launched a program for ordinary citizens to communicate the stories of A-bomb survivors (bibakusha in Japanese) and their desire for peace in 2012. Since then, she has visited Peru, Mongolia, and Iceland to share hibakusha accounts. In an interview before her visit to Poland in 2015, she said, "many Jews were killed because of racial discrimination, and innocent civilians were killed in Hiroshima. I want to convey how human rights are abused at a time of war." 30

Two Japanese memory agents hold different, almost opposite, views on the mnemonic connectivity and historical comparability of Auschwitz and Hiroshima. If the Auschwitz tour guide sticks to the incommensurability of the Holocaust, the Hiroshima memory keeper unreservedly compares Auschwitz and Hiroshima. This difference may come from the differences in the training they received: Nakatani's training to be an Auschwitz guide combined the official memory of Poland and Israel, while Hirano's practice as a voluntary memory keeper in Hiroshima epitomizes the dominant discourse of A-bomb victimhood in Japan. The divide between those Japanese memory agents indicates the complexity of the AuschwitzHiroshima connection.

Nevertheless, A-bomb victims in Japan were already invoking the Holocaust in "year zero"-1945. The first sign of entanglement appeared on November 23, 1945, in Nagasaki. At a memorial mass for Catholic hibakusha, Nagai Takashi delivered a funeral oration to about 600 survivors holding 8000 small white crosses to represent the Catholic victims. The speech reportedly moved the whole congregation to tears. ${ }^{31}$ The original manuscript of Nagai's funeral address reads: "The atomic bomb was originally destined for the prefectural offices at the center of Nagasaki. But because of weather conditions, the wind carried the plane north to Urakami, and the bomb exploded above the cathedral there ... we want to believe that the Urakami church was chosen not as a victim but as a pure lamb, to be slaughtered and burned on the altar of sacrifice to expiate the sins committed by humanity in the Second World War." The redemptive

\footnotetext{
${ }^{30}$ Sakiko Masuda, “'Memory Keeper' Yumie Hirano to visit Poland in May, Convey Survivors' Experiences of Atomic Bombing," The Chugoku Shinbun, April 18, 2018, http:// www.hiroshimapeacemedia.jp/?p=59331.

${ }^{31}$ For this and what follows: Konishi Tetsuro, "The Original Manuscript of Takashi Nagai's Funeral Address at a Mass for the Victims of the Nagasaki Atomic Bomb," Journal of Nagasaki University of Foreign Studies, no. 18 (2014): 55-68.
} 
discourse apparent in the African diaspora's invocation of the Jewish exodus reappears again in postwar Nagasaki.

Nagai went on to say, "We want to believe that only the sacrificial victim of Urakami could bring the war to an end; by this sacrifice, billions who would otherwise have fallen victims to the ravages of war have been saved." Then, Nagai picked out the word hansai (燔祭), the Japanese translation of the term "holocaust" from Chapter 22 of the Old Testament book of Genesis, to illustrate the sublime world-redemptive suffering of the A-bomb victims: "How noble, how splendid was that holocaust of 9 August, when flames soared up from the cathedral, dispelling the darkness of war and bringing the light of peace!" Nagai's speech is one of the earliest recorded public uses of "holocaust" in the postwar global memory space. Considering that the term was not popular even in Israel and the "West" until the late 1950s, his 1945 reference seems all the more remarkable. ${ }^{32}$

Nagai's use of "holocaust" was not a direct reference to Auschwitz, but it invited a comparison in some aspects at least. With its biblical semiotics, hansai contributed to sacralizing meaningless death into holy sacrifice to atone for the sins of humankind and contribute to universal salvation. But the sublimation of victims (bigaisha) into sacrifices (giseisha) also fed a nationalist project. Political religion comes into being by conferring a holy status on earthly entities like the nation, state, class, history, and race. It binds the individual to the sacralized secular body through a code of ethical and social commandments. ${ }^{33}$ The sacralization of the nation activates suppressed memories of suffering incurred in the national project under the aura of sacrifice. ${ }^{34}$ In this sense, Nagai's thesis that placed Urakami

\footnotetext{
${ }^{32}$ For the earliest uses of Holocaust in the West, see Steve Friess, "When 'Holocaust' became 'The Holocaust'," The New Republic, May 18, 2015, https://newrepublic.com/ article/121807/when-holocaust-became-holocaust See also Sean Warsch, "A 'holocaust' Becomes 'the Holocaust'," The Jewish Magazine, http://www.jewishmag.com/107mag/ holocaustword/holocaustword.htm; Jon Petrie, "The secular word Holocaust: Scholarly myths, history, and 20th century meanings," Journal of Genocide Research 2, no. 1 (2000): 31-63.

${ }^{33}$ Emilio Gentile, "The Sacralisation of Politics: Definitions, Interpretations and Reflections on the Question of Secular Religion and Totalitarianism," Totalitarian Movements and Political Religions 1 (2000): 18-55.

${ }^{34}$ See Jie-Hyun Lim, "Victimhood Nationalism in Contested Memories-National Mourning and Global Accountability," in Memory in a Global Age: Discourses, Practices and Trajectories, eds. Aleida Assmann and Sebastian Conrad (Basingstoke: Palgrave Macmillan, 2010), 138-62.
} 
Cathedral at the center of a holocaust enriched the psychological texture of Japanese victimhood nationalism.

In postwar Japan, Auschwitz and Hiroshima were frequently cited as terrible twin symbols of man-made mass death and even singled out as two archetypical examples of White racism. ${ }^{35}$ The extensive Japanese press coverage of the Eichmann trial promoted the association of Hiroshima and Nagasaki with Holocaust. The poet and peace activist Kurihara Sadako drew a succinct analogy: "Of the world's two great holocausts, Auschwitz was a major atrocity carried out by the enemies of the victorious Allies; Hiroshima/Nagasaki was a major atrocity carried out by Allies." She even suggested that Hiroshima was worse than Auschwitz because hibakusha had to suffer from the after-effects of radiation exposure while Auschwitz had an end-point. ${ }^{36}$ Rarely tainted by sporadic anti-Semitism and Holocaust denial scandals, ${ }^{37}$ the analogy of Auschwitz and Hiroshima never disappeared from the Japanese mnemoscape.

Ran Zwigenberg has explored the intriguing case of the HiroshimaAuschwitz Peace March. Four Japanese memory agents-cum-anti-nuclear peace activists left Hiroshima in March 1962 to participate in the commemoration of the liberation of Auschwitz on January 27, 1963. Satō Kyōtsū, a Buddhist monk and a veteran of the Japanese imperial army, led the peace pilgrimage. He declared that its aim was "to deepen the connection between these two places of utmost suffering and tragedy in World War II." On the route to Auschwitz, they visited World War II memorial sites in Vietnam, Singapore, Israel, Greece, Yugoslavia, and Hungary. This can probably be characterized as the first mnemonic pilgrimage on a global scale covering the Euro-Asian memory space, and Zwigenberg's presentation of it as an early exemplar of cosmopolitan memory is relatively persuasive. ${ }^{38}$

${ }^{35}$ Ian Buruma, The Wages of Guilt: Memories of War in Germany and Japan (New York: New York Review of Books, 2015), 92-9; John W. Dower, "An Aptitude for Being Unloved: War and Memory in Japan," in Crimes of War: Guilt and Denial in the Twentieth Century eds. Omer Bartov, Atina Grossmann and Mary Nolan (New York: The New Press, 2002), 226.

${ }^{36}$ Sadako Kurihara, "The Literature of Auschwitz and Hiroshima," Holocaust and Genocide Studies 7 (1993): 77-106 (here 86, 87). The Japanese original was published in 1984.

${ }^{37}$ Rotem Kowner, "Tokyo Recognizes Auschwitz: The Rise and Fall of Holocaust Denial in Japan, 1989-1999," Journal of Genocide Research 3, no. 2 (2001): 257-72 (here 257, 259, and passim).

${ }^{38}$ Ran Zwigenberg, "Never Again: Hiroshima, Auschwitz and the Politics of Commemoration," Asia-Pacific Journal 13:3, no. 1 (2015): 1-22; See also Ran Zwigenberg, 
In practice, though, the Hiroshima-Auschwitz Peace March was more like a mnemonic obstacle race. First, Cold War ideology delayed its departure. The Japanese authorities refused to issue passports for the Japanese activists, on the grounds that they were displaying political bias in commemorating the crimes of Germans at Auschwitz and not the massacre committed by Soviet soldiers at Katyn. In contrast, People's Poland welcomed the Japanese peace activists, since from the perspective of the Polish communist party Hiroshima was a crime of American imperialism and the Peace March demonstrated its affinity with Nazism. Dziennik Polski, a Cracow newspaper, reported on the appearance of the Hiroshima peace delegates at the 1963 Auschwitz liberation commemorations. The report stressed Satō's advocacy of the A-bomb free Central Europe agenda propagated by the Polish government. ${ }^{39}$

But this involved an inverted memory of the Japanese empire that exposes the ambivalence of cosmopolitan memory. In this mnemoscape, Japan occupied a postcolonial rather than a postimperial position, as the "Pacific War" between Japan and the USA became just one episode in Japan's century-long struggle and defeat against the colonialism of the Western Great Powers. ${ }^{40}$ Within this frame, Japan could remain an innocent victim in the process of coming to terms with the wartime past. And the American crime against Japanese civilians represented by the A-bomb served to reinforce this, while the misery and suffering of Japan's Taiwanese, Korean, Chinese, Vietnamese, Indonesian, Filipino, and other Asian neighbors were consigned to oblivion. The Peace March participants regarded themselves as the authentic victims and heroic pacifists until they were confronted with the accusations of the Japanese war atrocities during the pilgrimage. And despite this challenge, the pilgrims carried on.

Moreover, ethnically non-Japanese victims remained marginalized in the cosmopolitan memory that associated Hiroshima with Auschwitz. Even Oe Kenzaburo, one of the writers and intellectuals most sensitive to the minority question, confessed that he had ignored the Korean A-bomb victims in his insightful reportage on anti-nuclear pacifism and memory in

Hiroshima: the Origins of Global Memory Culture (Cambridge: Cambridge University Press, 2014).

39 “Pierwszy dzień wolności...” Dziennik Polski, January 29, 1963.

${ }^{40}$ Sebastian Conrad, "The Dialectics of Remembrance: Memories of Empire in Cold War Japan," Comparative Studies in Society and History 56 (2014): 4-33 (here 13, 17-18). 
Hiroshima. ${ }^{41}$ The ethnocentric memory of their own victimization blocked the sensibility among many Japanese for the suffering of others under Japanese occupation. Remembering Hiroshima and Nagasaki quickly became a way of forgetting Nanjing, Bataan, comfort women, and other Japanese atrocities. ${ }^{42}$ Rather, in interviews with hibakusha, reflections on the moral adequacy of the desire for revenge against Germans and Americans respectively, could evoke tirades against the vengefulness of the Koreans. ${ }^{43}$ As James Orr puts it, Hiroshima became “an icon of Japan's past as an innocent war victim and a beacon for its future as a pacifist nation." ${ }^{44}$ Yoneyama Lisa offers a more radical diagnosis, arguing that "the claim to posit a universal category of humanity as the subject of memorialization serves to obstruct condemnation of Japanese nationalism and ethnocentrism." 45

One cannot but be sceptical about the "cosmopolitan memory" connecting Hiroshima and Auschwitz in the 1960s. In the death diplomacy of exchanging the ashes of unidentified victims between the two sites, for example, it vulgarized the memento mori of the genocide. Moreover, it implied the nationalist appropriation of the Holocaust on the Japanese side as well as its ideological instrumentalization on the Polish side. In the Euro-Asian space it worked as a screen memory to cover the suffering of those subject to Japanese colonialism-a function similarly fulfilled by an obsessive interest in Anne Frank. Almost every Japanese has learned something about Anne Frank through the diary, manga comic book adaptations, or anime films. And as French journalist Alain Lewkovitz explains, "the Anne Frank-Japan connection is based on a kinship of victims ... [But t] hey don't think of the countless Anne Franks their troops created in Korea and China..." $" 46$

${ }^{41}$ See Kenzaburo Oe, "Preface to the English edition," in Hiroshima Notes, trans. D. L. Swain and T. Yonezawa (New York: Marion Boyars, 1995), 9. The Japanese original was written in 1963.

${ }^{42}$ John Dower, "The Bombed: Hiroshima and Nagasaki in Japanese Memory," Diplomatic History 19, no. 2 (1995): 275-95 (here 281).

${ }^{43}$ Robert Jay Lifton, Death in Life. Survivors of Hiroshima (Chapel Hill: University of North Carolina Press, 1991), 322.

${ }^{44}$ James J. Orr, The Victim as Hero: Ideologies of Peace and National Identity in Postwar Japan (Honolulu: University of Hawaii Press, 2001), 52.

${ }^{45}$ Lisa Yoneyama, Hiroshima Traces: Time, Space, and the Dialectics of Memory (Berkeley: University of California Press, 1999), 25.

${ }^{46}$ Quoted in Jewish Telegraphic Agency, "Why Are the Japanese So Fascinated With Anne Frank?" Haaretz, January 22, 2014, https://www.haaretz.com/jewish/anne-frank-thejapanese-anime-1.5314070. 
The Japanese career of Saint Maksymilian Kolbe is less well known than the Anne Frank syndrome, and it is much more complicated. Canonized in 1982 as a martyr for agreeing to be killed in Auschwitz in place of a fellow-inmate, Father Kolbe had spent time in Nagasaki as a missionary between 1930 and 1936. During those years, Nagai Takashi, the funeral orator of 1945 and himself known as the saint of Nagasaki, had visited Father Kolbe in the Hongochi monastery in Nagasaki and recorded his admiration for the priest. As the historical centre of Japanese Catholicism, Nagasaki was the focus of memory of the past persecution of Catholics in Japan. Kolbe's career at key sites of national and Catholic martyrdom promoted a very particular mnemonic nexus of Polish and Japanese (Catholic) victimhood. The moves for his beatification in 1971 and canonization in 1982 involved efforts to strengthen that nexus. ${ }^{47}$

Endō Shūsaku, a famous Catholic liberal novelist, published the serial novel Onna no isshō in the popular progressive daily newspaper Asabi Shimbun in 1980-1982. ${ }^{48}$ The novel intertwines the love story between two young Christians in wartime Nagasaki with Father Kolbe's martyrdom at Auschwitz. The resulting impression is that the deaths of both Nagasaki and Auschwitz victims were the work of Providence, a redemptive self-sacrifice for the sake of the peaceful future of humankind. Endo Shūsaku's short essay depicting Father Kolbe's death in Auschwitz featured in high school literature textbooks and is and still widely read among Japanese teenagers. In his interpretation, the highest love is to sacrifice one's own life to save that of another-an act of altruism that deserves the name miracle (kiseki). ${ }^{49}$

It is intriguing to note that Sono Ayako, one of Japanese Prime Minister Abe's informal advisers, provoked an online storm by writing that South Africa's apartheid policies had been good for Whites, Asians, and Africans. She has praised apartheid as a model of how Japan could expand

\footnotetext{
${ }^{47}$ See Jie-Hyun, Lim, "Kimyōna Hēchi-Makisimiriano Korubeto Nagasaki Hibakushano Shinsēka (A Strange Juxtaposition-Maximilian Kolbe and the Sacralization of the Nagasaki A-Bomb Victims)," in Sengo Nihon Bunka Saiko, ed. Tsuboi Hideto (Tōkyō: Sanninsha, 2019), 74-103.

${ }^{48}$ English edition: Endō Shūsaku, Sachiko, trans. Van C. Gessell (New York: Columbia University Press, 2020).

${ }^{49}$ Endō Shūsaku, "Korube Shinpu," Shinpenkokugos̄ōō Kaitēeban (Tōkyō: Taishukanshoten, 2018), 186.
} 
immigration. ${ }^{50}$ Sono's ultra-nationalist and racist public remarks are well known, but the fact that she has been an admirer of Father Kolbe is not. Two years after his beatification, she published the novel Kiseki (miracles), which includes a documentary biography and a fictional narrative in which the protagonist travels in search of the sites and the truth of Kolbe's miracles. Sono's interpretation of "miracle" shares with that of the liberal Endō Shūsaku its emphasis on the highest love to sacrifice one's own life to save another, though she is more fascinated with the patriotic myth of Father Kolbe and his family. ${ }^{51}$

It is not particularly surprising that the story of a Polish Catholic martyr became entangled with the history of the suffering of Japanese Catholics in Nagasaki. Kolbe's missionary life really was entwined with the lives of the Catholic hibakusha there. But a key element of his story is missing from the Japanese reception. The agents of Japanese memory have maintained total silence on the question of Kolbe's antisemitism, and this is true even among progressive Catholic intellectuals in Japan. When his beatification was announced in 1971, Jan Józef Lipski pointed out the antisemitic tendencies of Kolbe's journal Maty Dziennik..$^{52}$ And public discussion of Kolbe's antisemitism was not confined to Poland; his canonization in 1982 reignited the controversy, which the New York Times and Washington Post widely covered. ${ }^{53}$ The silence of Japanese Catholics on Kolbe's antisemitism cannot be easily explained. Finding an explanation would help us to assess Japanese memory culture in the postwar period.

\footnotetext{
${ }^{50}$ Elaine Lies and Takashi Umekawa, "Japan PM ex-adviser praises apartheid in embarrassment for Abe," Reuters, February 13, 2015, https://www.reuters.com/article/japan-apartheid / japan-pm-ex-adviser-praises-apartheid-in-e mbarrassment-forabe-idUSL4N0VN1PV20150213.

${ }^{51}$ Sono Ayako, Miracles: A Novel, trans. Kevin Doak (Portland, ME: Merwin Asia, 2016), 15, 63, 68, 101-2. See also Phillip Gabriel, Spirit Matters: The Transcendent in Modern Japanese Literature (Honolulu: University of Hawaii Press, 2006).

${ }^{52}$ Jan Józef Lipski, “Ojciec Kolbe i Mały Dziennik,” Tygodnik Powszechny, Nr. 38 (1182), 19. IX. 1971.

${ }^{53}$ Richard Cohen, "Sainthood," Washington Post, December 14, 1982; Binder, "Franciszek Gajowniczek Dead; Priest Died for Him at Auschwitz," New York Times, March 15, 1995; John Gross, "Life Saving," The New York Review of Books, February 17, 1983; Daniel Schlafly, Warren Green and John Gross, "Kolbe and Anti-Semitism," The New York Review of Books, April 14, 1983.
} 


\section{COMfort Women, American-Armenians, and Performative Nationalism}

A monument to the Korean comfort women was unveiled in front of the Bergen County courthouse in New Jersey on March 8, International Women's Day, in 2013. Alongside monuments commemorating American slavery, the Holocaust, the Armenian genocide, and the Irish potato famine, a new memorial stone to Korean comfort women took its place in the county's "ring of honor," part of a memory island outside the courthouse. The event exemplified the transpacific migration of the memory of the Korean comfort women. The institutional collaboration between the Korean American Civic Empowerment (KACE) organization and the Kupferberg Holocaust Center accelerated that transpacific memory campaign. The two jointly organized a meeting of Korean comfort women and Jewish American Holocaust survivors in the auditorium of Queensborough Community College on December 13, 2011-a striking example of the global entanglement of migrated memories. The meeting received broad media coverage in Korea. ${ }^{54}$

The mnemonic confluence of the Holocaust and comfort women in New York City epitomizes the extraterritoriality of a global memory of World War II. However, Japanese deniers of the comfort women history and nationalist memory activists began to mobilize in the transpacific memory space too. They appealed to the White House, Congress, and local governments to remove the comfort women monuments by arguing that comfort women were volunteer prostitutes and complaining that Korean nationalists were lying in order to dishonor the Japanese nation. The USA thus became a battlefield as the East Asian memory wars overflowed into the transpacific memory space. The damage done to the regional anti-communist alliance by the memory competition around forced labor and the comfort women is indicated by 2019's accelerating crisis in relations among the parties to the GSOMIA (General Security of

\footnotetext{
${ }^{54}$ No Ch’anghyon, “mi chŏngbu lho wianbugirimbi nyujŏjisŏ chemakshik," Newsis, March 9, 2013, https://newsis.com/view/?id=NISX20130309_0011904596; Korean American Civic Empowerment, "Compilation of News Articles on Comfort Women Survivors and Holocaust Survivors' Meeting," December 21, 2011, accessed March 8, 2020, http://us.kace.org/2011/compilation-of-news-articles-on-comfort-women-survi vors-and-holocaust-survivors\%27-meeting/.
} 
Military Information Agreement)-South Korea, Japan, and the USA. ${ }^{55}$ Following Bergen County, the City Council of Glendale, California, approved plans for a monument to the Korean comfort women by a vote of four to one on July 9, 2013. Despite the lobbying of Japanese nationalists, Glendale City Council was determined on the comfort women issue. There are two Armenian names, Ara Najarian and Zareh Sinanyan, among those of council members who voted for the plan. ${ }^{56}$ Given that Armenian Americans make up about $40 \%$ of the city's 200,000 inhabitants, making it the second biggest Armenian settlement in the world after Yerevan, the presence of two of them on the council is not surprising. ${ }^{57}$ What is intriguing is the address made by Armenian-American Council members at the unveiling of the comfort women statue.

Ara Najarian called the unveiling "a moment of pride for the City of Glendale" and expressed his hope that the monument could be "a part of the healing process" for the surviving comfort women. Zareh Sinanyan, the first Armenian-born politician to sit on the Glendale City Council and the grandson of an Armenian genocide survivor, also spoke, emphasising how his own memory of the Armenian genocide and its denial by the Turkish state had made him sensitive to the comfort women issue. Presumably, the political calculation of appealing to Glendale's 20,000 Korean-American residents also informed his speech.

Still more impressive for its display of cosmopolitan memory is the ReflectSpace Gallery in Glendale City Library. Designed to explore and reflect on major human atrocities, ReflectSpace provides a range of exhibits on memories. ${ }^{58}$ The inaugural exhibition, "Landscape of Memory: Witnesses and Remnants of Genocide," in May-June 2017 reflected on the Armenian Genocide through the cross-disciplinary work of witnesses, survivors, and artists. The second exhibition, "Do the Right Thing," which focused on the comfort women, was presented between July 20 and September 3, 2017. Armenian Americans Ara and Anahid Oshagan and

${ }^{55}$ Choe Sang-Hun, "South Korea Resists U.S. Pressure to Improve Ties With Japan,” New York Times, November 15, 2019, https://www.nytimes.com/2019/11/15/world/asia/ south-korea-japan-intelligence-sharing.html.

${ }^{56}$ Rafu Staff, "Glendale Approves Comfort Women Memorial," Rafu Shinpo, July 15, 2013, http://www.rafu.com/2013/07/glendale-approves-comfort-women-memorial/.

${ }^{57}$ Chris McCormick, "Armenian Exceptionalism," The Atlantic, April 4, 2016, https:// www.theatlantic.com/business/archive/2016/04/glendale-armenians/475926/.

58 "ReflectSpace," City of Glendale, accessed March 17, 2020, https://www.glendaleca. gov/government/departments/library-arts-culture/reflectspace. 
Korean American Monica Hye Yeon Jun co-curated works by twelve international documentarians and artists. The exhibition's key theme was the "tension between the inability to speak about personal trauma and the deep human urge to tell" characteristic of many survivor experiences. ${ }^{59}$ Subsequent exhibitions "Wake: The Afterlife of Slavery," "i am: Narratives of the Holocaust," "in/visible-Negotiating the US-Mexico Border," and "Nonlinear Histories-Transnational Memory of Trauma" show explicitly how dedicated the gallery is to mapping the global memory space.

It is heartening to note that in stark contrast to the position taken by Japanese-American right-wing nationalists Rafu Shimpo, the JapaneseAmerican community newspaper in Little Tokyo in Los Angeles, published a very sympathetic report on the unveiling ceremony. The NCRR (Nikkei for Civil Rights \& Redress) has also been supportive of commemorating comfort women in the USA. The NCRR was founded in 1980 to call for compensation and redress for 120,000 Japanese Americans interned during World War II. It helped many internees to speak out at the 1981 hearings of the Commission on Wartime Relocation and Internment of Civilians. At the same time, it actively supported memory activism around the comfort women as part of a wider commitment to emancipatory memory politics and fighting discrimination. After September 11, 2001, the NCRR established a 9/11 Committee to collaborate with the Muslim Public Affairs Council, the Council on AmericanIslamic Relations, and the American Arab Anti-Discrimination Committee. ${ }^{60}$

The unanticipated collaboration of the Armenian-American community and Japanese Americans of the NCRR in commemorating Korean comfort women in Glendale is an example of vernacular cosmopolitan memory in which mnemonic solidarity almost seems to have been realized. A closer look, however, reveals a more complex picture. Zareh Sinanyan had to apologize for posting racist, homophobic, and vulgar comments on YouTube, "many of which appeared centered around Armenia's geopolitical enemies" 1 —actions in stark contrast with the

\footnotetext{
${ }^{59}$ Chuck Wike, "New Exhibition at Downtown Glendale Central Library: Do the Right Thing-(dis)comfort women," City of Glendale, accessed March 17, 2020, https://www. glendaleca.gov/Home/Components/News/News/5389/1097? arch=1\&npage=12 .

60 "About NCRR," NCRR-Nikkei for Civil Rights and Redress, accessed March 8, 2020, http://www.ncrr-la.org/about.html.

${ }^{61}$ Brittany Levine, "Glendale Councilman Zareh Sinanyan apologizes for racist postings," Los Angeles Times, May 1, 2013.
} 
solidary sentiments of his Glendale speech. Moreover, in a private talk with Korean-American memory activists, Sinanyan disagreed with the comparison they made between the Armenian genocide and the Japanese military sexual slavery. ${ }^{62}$ His remarks implied that only the Holocaust is actually comparable to the "Armenocide," which should not be placed on a par with the petty tragedy of the comfort women. Mnemonic solidarity remains subject to the agony of competition.

To be sure, the globalization of the comfort women issue would hardly have been possible without mnemonic solidarity. Until the early 1990s, comfort women were silenced and erased from the national and regional memory in East Asia. ${ }^{63}$ Even when the suppressed memory surfaced in Korea in 1991, it remained a matter of "nationalized sexuality": When memory activists proposed building a monument at Independence Hall of Korea, they were turned down on the pretext that there was not enough space in the most spacious memorial site in Korea. Comfort women did not fit the Hall's heroic narrative. Postcolonial Korea's dominant patriarchal memory thus marginalized and suppressed a key dimension of the country's wartime suffering. ${ }^{64}$

It was the heightened sensitivity to sexual violence provoked by the civil war in former Yugoslavia and the Rwandan genocide that moved the comfort women into the global mnemospace. A reflection on the sexual abuse in former Yugoslavia sharpened the awareness of women's rights as an inalienable, integral, and indivisible part of human rights. The International Criminal Tribunals for the former Yugoslavia and Rwanda (ICTY and ICTR) included rape as a crime against humanity, providing a language for the Women's International War Crimes Tribunal on Japan's Military Sexual Slavery that convened in Tokyo in $2000 .{ }^{65}$ The composition of the Tokyo tribunal itself demonstrates the significance of the global memory space. Gabrielle Kirk McDonald, the former president of the ICTY, and Patricia Viseur-Sellers, Legal Advisor on Gender Related Crimes to both the ICTY and ICTR, acted as judges and chief prosecutors. Eight regional

\footnotetext{
${ }^{62}$ General Secretary of KACE, in discussion with the author, KACE Office, New York City, July 4, 2014.

${ }^{63}$ See Carol Gluck's chapter in this volume.

${ }^{64}$ Hyunah Yang, "Hankookin gunwuianburŭl giŏkhandanŭngeot (Remembering Korean comfort women)," in Wibömban Yosong [Dangerous Women], eds. Elaine H. Kim and Chungmoo Choi, trans. Eunmi Park, (Seoul: Samin, 2002), 157-76 (here 175).

${ }^{65}$ Maki Kimura, Unfolding the "Comfort Women" Debates: Modernity, Violence, Women's Voices (Basingstoke: Palgrave Macmillan, 2016), 6-8.
} 
teams of prosecutors, including a joint team from South and North Korea, presented cases on behalf of the former comfort women. ${ }^{66}$

The judgment of the Tokyo Tribunal did not carry legally binding force. But its conviction of the Japanese state and the dead emperor Hirohito for "war crimes and crimes against humanity" had symbolic significance. The final judgment reads: "The crimes committed against the survivors remain one of the great unremedied injustices of the Second World War. There are no museums, no graves for the unknown comfort woman, no education of future generations, and no judgment days, for the victims of Japan's military sexual slavery. Many of the women who have come forward to fight for justice have died unsung heroes." ${ }^{67}$ As Carol Gluck argues in this volume "Just as the Holocaust became a global example of genocide, so did the comfort women become a touchstone for new international law relating to the violence against women in war."

If Korean nationalism initially operated to suppress the memory of the comfort women, this opening up of a global conversation about them has also drawn nationalist memory activists into the commemoration business. The aborted plan to install a comfort women statue in the German city of Freiburg offers another insight the multiple political uses of a memory icon and also into the ways in which mnemonic solidarity can be buffeted by the cross-currents of global-transnational and local memory politics. In September 2016 Tae-young Yeom, the mayor of the South Korean city of Suwon, proposed to send a comfort woman statue to Suwon's partner city Freiburg. Initially, Freiburg's mayor Dieter Salomon welcomed it as the kind of gift that is usual between sister cities. As a committed Green Party politician, Salomon was also memory-conscious, an advocate of critical engagement with Germany's Nazi past. But he had to withdraw his decision, partly because of local voices arguing that it would be a scandal to build a comfort woman statue when there was not yet any memorial to the victims of German wartime sexual slavery and violence. The angry reaction from citizens of Matsuyama, Freiburg's partner city in Japan, also inclined Mayor Salomon to rethink his original move. ${ }^{68}$

${ }^{66}$ Rumi Sakamoto, “The Women's International War Crimes Tribunal on Japan's Military Sexual Slavery: A Legal and Feminist Approach to the 'Comfort Women' Issue," New Zealand Journal of Asian Studies 3 (2001): 49-58 (here 49-50).

${ }^{67}$ Judges of the Women's International War Crimes Tribunal on Japan's Military Sexual Slavery, "Transcript of Oral Judgment," December 4, 2001, accessed March 8, 2020, http://iccwomen.org/wigjdraftl/Archives/oldWCGJ/tokyo/summary.html.

${ }^{68}$ Esther Felden, "Freiburg und die Trostfrau," Dentsche Welle, September 21, 2016, http://www.dw.com/de/freiburg-und-die-trostfrau/a-19563885. 
The story does not end here. In November 2016, The Korean Council for the Women Drafted for Military Sexual Slavery by Japan, a nationalist feminist NGO, made Mayor Yeom the first to win the Council's special prize designed for local policymakers who promote and globalize the comfort women issue. ${ }^{69}$ On International Women's Day in 2017, thanks to Mayor Yeom's tireless efforts, a replica of the comfort woman statue that stands in front of the Japanese embassy in Seoul was unveiled in the Nepal-Himalaya-Pavillon in Wiesent, a Bavarian village with a population of under $2500 .^{70}$ Neither German nor Korean media reports explain why the Nepal-Himalaya-Pavillon in Wiesent was chosen for this gesture.

This event was performed entirely out of context, out of history, and out of memory. Perhaps it was not the German residents of Wiesent, but the Korean voters at home that the comfort women statue was designed to address. Around the same time, the provincial assembly of Gyunggi-do province, to which Suwon belongs, resolved to erect a comfort woman statue on Dokdo/Takeshima-a cluster of rocks in the Sea of Japan which is the subject of an angry territorial dispute between Korea and Japan. As the chairperson of Gyunggi-do provincial assembly stressed the principle of "human rights" in this resolution, ${ }^{71}$ he revealed the open secret of how mnemonic nationalism appropriates and vulgarizes cosmopolitan memory. The global memory space provided Korea's Quixotic nationalists with a brand new playground, and local politicians were able to exploit Korean victimhood nationalism, which is deeply rooted at the local government level, to raise their national and even global profiles. Memory activism around the comfort women still threatens to reinforce a victimhood nationalism that has become more performative, visualized, intimate, and entrenched in the everyday life of postcolonial Korea.

${ }^{69} \mathrm{Yi}$ Minu, “yŏmt'aeyŏng suwŏnshijang, chŏngdaehyŏp t'rt'ŭkpyŏlsangt' susang," Newspeak, November 21, 2016, http://www.newspeak.kr/news/articleView.html?idxno= 116422.

${ }^{70}$ Stefan Gruber, “'Trostfrau' mahnt zum Frieden,” Mittelbayeriscshe Zeitung, March 12, 2017, https://www.mittelbayerische.de/region/regensburg-land/gemeinden/wiesent/ trostfrau-mahnt-zum-frieden-21411-artl496089.html. My thanks to Tanja Vaitulevich for the information of this bizarre event.

${ }^{71}$ Hong Yong Duck, "kyŏnggidoŭihoe orhae ane toktoe p'yŏnghwaŭi sonyŏsang seugiro," Hankyoreh, January 16, 2017, http://www.hani.co.kr/arti/society/area/778 893.html. 


\section{Critical Relativization in Postcolonial Perspective}

The mnemonic confluence of the Holocaust, colonialist crimes, and Stalinist terror characterizes global memory formation in the post-Cold War era, an era in which "multidirectional memory" is not yet free from hegemonic memory politics. ${ }^{72} \mathrm{~A}$ reflection on the ways in which memories of Holocaust and Gulag, of Auschwitz and Nagasaki, of the Armenian genocide and the comfort women, of Mississippi, Robben Island and the Generalgouvernement, have been and might be globally connected reveals a tension inherent in the global memory formation itself. Whether at the official or the vernacular level, remembrance is permanently pulled between forces of de-territorialization and re-territorialization. The simple generic juxtaposition of three traumas (or victimhoods) - or any two of them-does not necessarily produce a rosy cosmopolitan memory. National memories have competed for the status of hegemon in global memory formation, and the result has been the hierarchization of victimhood. In post-communist Eastern Europe and the postcolonial tricontinent, what promised to be a cosmopolitan memory of Holocaust has been appropriated to serve mnemonic nationalism. In places where victims and victimizers cohabit, an indigenized Holocaust remembrance has worked as a screen memory to veil the dark history of the victims' own crimes.

Cosmopolitan memory is thus not free from nationalist appropriation. Indeed, against our expectations, it provides mnemonic nationalism with persistent moral leverage, thus intensifying the struggle for mnemonic hegemony among conflicting national memories. Holocaust memory as it circulates globally is particularly vulnerable to nationalist appropriation, perhaps because it occupies a position of absolute morality. ${ }^{73}$ And the unique success of Holocaust survivors in claiming material restitution makes their moral claim, in all its absoluteness, an object of emulation for other traumatized groups. It is a paradox but no surprise

\footnotetext{
${ }^{72}$ See Rothberg, Multidirectional Memory.
}

${ }^{73}$ The verdict of the European Court of Justice on December 17, 2017 that denying the Armenian genocide belongs to the domain of the freedom of speech, while the denial of the Holocaust is a crime transcending the freedom of speech, is a case in point. See Ofer Aderet and Reuters, "European Court: Denying Armenian 'Genocide' Is No Crime: Judges draw distinction between Armenian case and the Holocaust of the Jews," Haaretz, December 18, 2013, https://www.haaretz.com/european-court-no-crime-to-deny-armenian-genocide1.5301268 . 
that the Holocaust as an object of cosmopolitan memory is frequently abused to justify nationalist remembrance in Eastern Europe and East Asia in the post-Cold War era. This is not because the Holocaust has "no real resonance" outside of Europe, Israel, and the USA. ${ }^{74}$ Israel, the USA, and Western Europe were never reluctant to politicize, instrumentalize, and abuse Holocaust memory. If anything, the presence of real survivors in the "Western" countries made it easier to authenticate, justify, and facilitate the politicization of the Holocaust memory. In short, the cosmpolitanization of the Holocaust has intensified mnemonic nationalism as much as it has contributed to mnemonic solidarity in the global memory formation.

Zygmunt Bauman's warning that the Holocaust is a logical outcome not of premodern barbarity, but of Western modernity gives us a clue to how to connect postcolonial criticism to global memory formation in the post-Cold War era. His postmodernist critique of the Holocaust disquiets "the moral comfort of self-exculpation" by the non-German West by shattering the complacent binary of mad perpetrators and innocent victims. If it is a "legitimate outcome of the civilizing process" in modern society, the Holocaust becomes "our" problem beyond the German-Jewish encounter. $^{75}$ In the same way, a postcolonial critique can alert us to the mnemonic nationalism inherent in triple victimhood claims. Attentiveness to the ways in which anti-colonial nationalism operates not as an alternative but as an accomplice to colonialism exposes the ambivalence of colonialist desire and frustration among the colonized. It can help us to rescue the memory of colonial victimhood in the tri-continent from mnemonic nationalism. And the critical gaze of postcolonialism can be extended to Eastern Europe, where the analogy between the Slavic East under the Nazi occupation of the "Third Europe," the socialist colonies under the Stalinist red empire, and the postcolonial states of the "Third World" was familiar. The postcolonial entanglement of triple victimhood is one of keys to understanding the global memory formation in the post-Cold War era.

By way of conclusion, I propose critical relativization and radical juxtaposition as antidotes to the nationalist appropriation of cosmopolitan memory. This is different from what came to be known as the relativization of the Holocaust in the course of the German Historikerstreit of the

${ }^{74}$ Alon Confino, "The Holocaust as a Symbolic Manual: The French Revolution, the Holocaust, and Global Memories," in Marking Evil: Holocaust Memory in the Global Age eds. Amos Goldberg and Haim Hazan (New York: Berghahn Books, 2015), 56-70 (here 56).

${ }^{75}$ Bauman, Modernity and the Holocaust, xii, 28. 
late 1980s, when Ernst Nolte and other right-wing historians proposed to "explain"-and in effect justify-the crimes of National Socialism by presenting Nazism as a response to Bolshevik terror. ${ }^{76}$ This episode developed into a debate about West German national identity which was substantially overtaken by the end of the Cold War. It briefly tarnished comparative approaches and challenges to the historical uniqueness of the Holocaust with the suspicion of apologetic nationalism. But comparison remains a critical methodology in historical studies, and in any case, as Charles Maier argued then, "comparability cannot really exculpate." 77

What matters is not generic relativization or comparability but the "political relativization of responsibility." 78 For example, the focus on the human actors and questions of responsibility allows us to interrogate assertions of the historical uniqueness or ineffability of the Holocaust, and more particularly those that subsume the complex Holocaust events into the mass murder of a single people, the Shoah. As Geoff Eley pointed out at the time of the Historikerstreit, the exclusive focus on Shoah "tends to free other, less universally abhorred aspects of Nazism (like the crimes against labor), let alone other parts of the killing program (like the murder of gypsies, Poles, Soviet P.O.W.s, homosexuals, and so on) from attention." ${ }^{" 79}$ We need to see even the mass murder of the Jews in the context of processes and practices that are open to both historical explanation and ethical and forensic judgment.

Arguably, the memory wars in post-communist Eastern Europe and postcolonial tri-continent represent a second, global wave of the Historikerstreit. Memories and narratives of the past are now more diverse, contradictory, localized, and multiple than they were when subject to ideological division on the single axis of the Cold War. The cosmopolitanization of Holocaust memory remains an undeniable phenomenon in the post-Cold War era. But the global memory formation involves more than the mere transposition of Holocaust memory onto colonial genocide and Stalinist terror. Neither, from the viewpoint of global memory formation,

\footnotetext{
${ }^{76}$ See Siobahn Kattago, Ambiguous Memory: The Nazi Past and German National Identity (Westport, CT: Praeger, 2001), 56-62; Geoff Eley, "Nazism, Politics and the Image of the Past: Thoughts on the West German Historikerstreit 1986-1987," Past \& Present, no. 121 (1988): 171-208 (here 173).

${ }^{77}$ Charles S. Maier, The Unmasterable Past: History, Holocaust and German National Identity (Cambridge, MA: Harvard University Press, 1997), 1.

${ }^{78}$ Ibid., xii.

${ }^{79}$ Eley, "Nazism, Politics and the Image of the Past," 174.
} 
are we required to make an either/or choice between uniqueness and relativization. What I call critical relativization should make it possible for us to consider other victims empathetically, and to resist the temptation of prioritizing our own victimhood. Similarly, the critical juxtaposition of different memories that avoids the compulsion to make systematic or causal connections can help us to perform non-hierarchical acts of comparison in the global memory space. ${ }^{80}$

${ }^{80}$ On critical juxtaposition, see Susan Stanford Friedman, "Planetarity: Musing Modernist Studies," Modernism/Modernity 17, no. 3 (2010): 471-99 (here 493-94). 
Open Access This chapter is licensed under the terms of the Creative Commons Attribution 4.0 International License (http://creativecommons.org/licenses/ by $/ 4.0 /$ ), which permits use, sharing, adaptation, distribution and reproduction in any medium or format, as long as you give appropriate credit to the original author(s) and the source, provide a link to the Creative Commons licence and indicate if changes were made.

The images or other third party material in this chapter are included in the chapter's Creative Commons licence, unless indicated otherwise in a credit line to the material. If material is not included in the chapter's Creative Commons licence and your intended use is not permitted by statutory regulation or exceeds the permitted use, you will need to obtain permission directly from the copyright holder. 